Brigham Young University Law School

BYU Law Digital Commons

Faculty Scholarship

$1-1-1997$

\title{
The United States Parol Evidence Rule under the United Nations Convention on Contracts for the International Sale of Goods
}

David H. Moore

BYU Law, moored@law.byu.edu

Follow this and additional works at: https://digitalcommons.law.byu.edu/faculty_scholarship

Part of the Contracts Commons, and the International Trade Law Commons

\section{Recommended Citation}

David H. Moore, The United States Parol Evidence Rule under the United Nations Convention on Contracts for the International Sale of Goods, 3 INT'L TRADE \& BUS. L. ANN., 57 (1997).

This Note is brought to you for free and open access by BYU Law Digital Commons. It has been accepted for inclusion in Faculty Scholarship by an authorized administrator of BYU Law Digital Commons. For more information, please contact hunterlawlibrary@byu.edu. 


\title{
The United States Parol Evidence Rule under the United Nations Convention on Contracts for the International Sale of Goods ${ }^{1}$
}

\author{
David H Moore
}

\section{Introduction}

The United Nations Convention on Contracts for the International Sale of Goods $^{2}$ (CISG or the Convention) has been in force since 1988. ${ }^{3}$ The Convention's purpose is at least two-fold: 'to assure a uniform regime for ... international sales contracts'; and to 'offer rules that will be more responsive than the traditional national laws to the effective needs of international trade'.4

In attempting to establish a uniform law for international sale of goods contracts, the Convention directs courts applying CISG to have 'regard ... to its international character and to the need to promote uniformity in its application'.5 In response to this directive, courts worldwide should consider

1 A version of this article has been published in 1995 Brigham Young University Law Review. The author wishes to thank Professor Gabriël Moens for reviewing this article.

2 United Nations Convention on Contracts for the International Sale of Goods, opened for signature 11 April 1980, S Treaty Doc no 9, 98th congress, 1st session 22 (1983) 19 Intermational Legal Materials 671 [hereinafter CISG]. For brief summaries of the Convention's history, see JO Honnold, Documentary History of the Uniform Law for International Sales 2-4 (Deventer, Netherlands: Kluwer Law and Taxation, 1989) [hereinafter Documentary History]; JO Honnold, Uniform Law for International Sales Under the 1980 United Nations Convention ss 4-10, 2nd edn (1991) [hereinafter Uniform Law]; K Sono, 'The Vienna Sales Convention: History and Perspective' in International Sale of Goods 1, 2-6 P Sarcevic and P Volken (eds) (1986); and DJ Rhodes, Comment, 'The United Nations Convention on Contracts for the International Sale of Goods: Encouraging the Use of Uniform International Law' (1992) 5 Transnational Law, 387, 391-95 (highlighting the United States' participation in that history). For bibliographic information on CISG, see CM Bianca and MJ Bonell, Commentary on the International Sales Law: The 1980 Vienna Sales Convention (Milan, Italy: Giuffre, 1987) 851-73; GR Ackerman, 'Scholarly Commentary on Articles of the United Nations Convention on Contracts for the International Sale of Goods' (1988) 21 Cornell International Law Journal 535, 537-73; and P Winship, 'A Bibliography of Commentaries on the United Nations International Sales Convention' (1987) 21 Intemational Law 585, as updated in P Winship, 'Bibliography', 22 International Law (1988) 605; $P$ Winship, 'A Bibliography of Commentaries on the United Nations International Sales Convention: An Update' (1990) 24 International Lawyer 307; and P Winship, 'The UN Sales Convention: A Bibliography of English Language Publications' (1994) 28 International Law 401. To access the legislative history of the Convention by current article number, consult the table in Documentany History, supra, 869-74.

3 J Honnold, 'Introduction to the Symposium' (1988) 21 Comell International Law Journal 419, 419-20; 'Joumal of Law and Commerce CISG Contracting States and Declarations Table' (1993) 12 Journal of Law and Commerce 283, 283 [hereinafter Declarations Table].

4 MJ Bonell, Introduction to Bianca and Bonell, supra note 2, 3, 9.

5 CISG, supra note 2, Article 7(1), S Treaty Doc no 9, at 23, 19 ILM 673. 
the decisions other nations have reached in applying the Convention. ${ }^{6}$ Over one hundred such decisions already exist. ${ }^{7}$ Eight of these decisions have been reached by United States' courts. ${ }^{8}$

The most recent reported United States case citing CISG, Beijing Metals and Minerals Import/Export Corp v American Business Centre, Inc, held that the parol evidence rule applies to contracts governed by the Convention. ${ }^{9}$

6 See E Diederichsen, 'Commentary to Journal of Law and Commerce Case I: Oberlandesgericht, Frankfurt am Main', 14 Joumal of Law and Commerce (1995) 177, 177 ('[C]onsideration has to be given to court decisions in the various countries concerning the interpretation of the CISG ...'); JO Honnold, 'The Sales Convention in Action - Uniform Intemational Words: Uniform Application?', 8 Joumal of Law and Commerce (1988) 207, 211 [hereinafter Uniform Application] ('In view of the mandate in Article 7(1) ... courts in States that adopt the Sales Convention should have no doubt as to their responsibility to consider interpretations in other countries.'); JO Honnold, 'Uniform Laws for International Trade: Early "Care and Feeding" for Uniform Growth', 1 International Trade and Business Law Journal (1995) 1, 8 [hereinafter Care and Feeding] ('[T]he Sales Convention's call for interpretation 'to promote uniformity in [the Convention's] application ...' [is] a mandate that clearly calls for due regard for interpretations in other countries.') (second alteration in original); $c f \mathrm{~K}$ Sutton, 'Methodology in Applying Uniform Law for International Sales (Under the UN Convention) (Vienna 1980)' in Law and Australian Legal Thinking in the 1980s (Sydney: University of Sydney; Melboume: Monash University, 1986) 91, 92 (' [] $\mathrm{f}$ a body of case law was established in relation to the Convention, no doubt the Australian judiciary would seek to follow it in the interests of uniformity. But the persuasive value of a particular judgment in a foreign court could depend on its reputation, its status, the extent to which its decisions were binding on inferior courts and the coverage of the national reporting system.') (discussing in general how Australia would apply the Convention). But $c f$ Bianca and Bonell, supra note 2, 92 ('A judge ... faced with a question of interpretation of the Convention may discover that ... divergent solutions have been adopted by the different national courts. As long as the conflicting decisions are rather isolated and rendered by courts of first instance, or the divergences are to be found even within one and the same jurisdiction, it is still possible either to choose the most appropriate solution among the different ones so far proposed or to disregard them altogether and attempt to find a new solution.'). To aid in the consideration of foreign decisions, 'UNCITRAL [(the United Nations Commission on International Trade Law) has] established procedures for gathering and disseminating decisions applying the Sales Convention' as well as for preparing, translating, and distributing summaries of those decisions. Uniform Law, supra note 2, s 93. For information on how to obtain copies of decisions from UNCITRAL, see Care and Feeding, supra, 9 and note 19.

7 See MR Will, Intemational Sales Law Under CISG 10 (1994) (charting over 100 cases mentioning CISG).

8 Four reported United States cases have cited CISG: Beijing Metals and Minerals Import/Export Corp v American Business Ctr, Inc, 993 F 2d 1178, 1182-83 note 9 (fifth cir 1993); Filanto SpA v Chilewich Int'l Corp, 789 F Supp 1229, 1237-42 (SDNY 1992), appeal dismissed, 984 F 2d 58 (second cir 1993); Orbisphere Corp v United States, 726 F Supp 1344, 1355 note 7 (Ct Int'1 Trade 1989); and Promaulayko v Amtorg Trading Corp, 540 A 2d 893, 897 note 2 (NJ Super Ct App Div 1988), rev'd on other grounds sub nom. Promaulayko v Johns Manville Sales Corp, 562 A 2d 202 (NJ 1989). Likewise, four unreported United States cases have cited the Convention: Graves Import Co v Chilewich Int'l Corp, no 92 Civ 3655 (JFK), 1994 WL 519996, 5 note 2 (SDNY 22 Sep 1994); Delchi Carrier, SpA v Rotorex Corp, no 88-CV-1078, 1994 WL 495787, 4-7 (NDNY 9 Sep 1994) (mem); SV Braun, Inc v Alitalia-Linee Aeree Italiane, SpA, no 91 Civ 8484 (LBS), 1994 WL 121680, 5 (SDNY 6 Apr 1994) (mem); and Interag Co v Stafford Phase Corp, no 89 Civ 4950 CSH, 1990 WL 71478, 4 (SDNY 22 May 1990) (mem). As one of the reported cases recognised, 'there is as yet virtually no United States case law interpreting the Sale of Goods Convention'. Filanto, 789 F Supp 1237. Yet, "it may safely be predicted that this will change [for] absent a choice-of-law provision, and with certain exclusions not here relevant, the Convention govems all contracts between parties with places of business in different nations, so long as both nations are signatories to the Convention'. Id (citing CISG, supra note 2, Article 1(1)(a), S Treaty Doc no 9, 22, 19 ILM 672).

9 Beijing Metals, $993 \mathrm{~F} 2 \mathrm{~d}$ at $1183 \mathrm{n}$ 9. This holding contradicts the dictum of the United States district court in Filanto that 'the Convention essentially rejects ... the parol evidence rule'. Filanto, 789 F Supp 1238 note 7. 
Perhaps because the court reached this conclusion without any recorded analysis, and only in footnote, the conclusion generated little or no commentary in periodical literature until the spring of this year. Then the court's holding was deemed incorrect in a well-reasoned article by Professor Harry M Flechtner. ${ }^{10}$ This article responds in part to that article, seeking to justify the court's elliptic conclusion in Beijing Metals.

At first glance this article's attempt to justify the Beijing Metals holding may appear to be an attack on the strictly international approach to CISG interpretation, an approach which many view as essential to the Convention's

10 HM Flechtner, 'More United States Decisions on the UN Sales Convention: Scope, Parol Evidence, "Validity" and Reduction of Price Under Article 50' (1995) 14 Joumal of Law and Commerce 153, 158. Others have similarly concluded that the parol evidence rule is largely inconsistent with CISG, though this article responds primarily to Professor Flechtner's article, which directly addresses the Beijing Metals holding. See Uniform Law, supra note 2, s 110, at 170-71 ('[T] he language of Article 8(3) ... seems adequate to override any domestic rule that would bar a tribunal from considering the relevance of other agreements.'); RA Brand and HM Flechtner, 'Arbitration and Contract Formation in International Trade: First Interpretations of the UN Sales Convention' (1993) 12 Joumal of Law and Commerce 239, 251, 252 ('By requiring consideration of 'all relevant circumstances' - including 'negotiations' - without excepting situations where the parties embodied their agreement in a writing, [Article 8(3)] does overrule certain traditional applications of the parol evidence rule'; yet "while the rather impenetrable applications of the parol evidence rule in our domestic law tradition should have little or no precedential value for contracts governed by CISG, the basic principles behind the rule remain viable under the Convention'.); JE Murray jr, 'An Essay on the Formation of Contracts and Related Matters Under the United Nations Convention on Contracts for the International Sale of Goods' (1988) 8 Journal of Law and Commerce 11, 44 ('CISG rejects the parol evidence rule in the most frugal terms.'); $P$ Winship, 'Domesticating International Commercial Law: Revising UCC Article 2 in Light of the United Nations Sales Convention' (1991) 37 Loy L Rev 43, 57 [hereinafter Domesticating International Law] (suggesting that the parol evidence rule is largely inconsistent with Article 8(3) of the Convention). The conclusion that CISG displaces the parol evidence rule finds some support in the Convention's legislative history. During the 7 th meeting of the 1st committee, the Canadian representative proposed the addition of a paragraph to current Article 11. 'UN Conference on Contracts for the International Sale of Goods' 1st committee, 7th meeting, 82, at 270, UN Doc A/Conf 97/19 (1980), in Documentary History, supra note 2, 491. The new paragraph would have restricted the admissibility of testimony contradicting a written contract. 'Report of the First Committee, UN Conference on Contracts for the International Sale of Goods' 1st committee, Article 10, 3, at 90, UN Doc A/Conf 97/19 (1980), in Documentary History, supra note 2,662. The proposed paragraph read: "Between the parties to a contract of sale evidenced by a written document, evidence by witnesses shall be inadmissible for the purposes of confuting or altering its terms, unless there is prima facie evidence resulting from a written document from the opposing party, from his evidence or from a fact the existence of which has been clearly demonstrated. However, evidence by witnesses shall be admissible for purposes of interpreting the written document.' Id. The Japanese representative objected to this proposal because he believed it to be essentially a 'restatement' of the rigid and difficult to apply parol evidence rule. 'UN Conference on Contracts for the International Sale of Goods' 1st committee, 7th meeting, 84, at 270, UN Doc A/Conf 97/19 (1980), in Documentary History, supra note 2,491 . Though at least two representatives favoured the amendment, the Canadian proposal 'did not seem to command wide support' and was not adopted by the Committee. 'UN Conference on Contracts for the International Sale of Goods' 1st committee, 7th meeting, 86, at 270, UN Doc A/Conf 97/19 (1980), in Documentary History, supra note 2, 491 . From this it might be assumed that the parol evidence rule was rejected by the drafters of CISG. However, the limitation on testimony proffered by the Canadian representative was triggered by the mere existence of a writing. 'UN Conference on Contracts for the International Sale of Goods' 1st committee, 7th meeting, 84, at 270, UN Doc A/Conf 97/19 (1980), in Documentary History, supra note 2,491 . Because the United States parol evidence rule, in contrast, is triggered by the integrationist intent of the parties, that rule was not explicitly rejected by the Committee along with the Canadian proposal. 
success and which decries the use of domestic law. ${ }^{11}$ The article should be viewed, however, as a healthy counterpoint to the widely-supported internationalist approach. As such a counterpoint, the article explores weaknesses in the strictly international position and may facilitate formulation of a more defensible strategy for applying CISG.

In seeking to justify the holding that the parol evidence rule applies to contracts governed by CISG, this article will first summarise the mechanics of the parol evidence rule. Next the article will review the facts and relevant holding of Beijing Metals. Finally, and most importantly, this article will develop two arguments supporting that holding: first, that the parol evidence rule is essentially an expression of CISG Article 8 and serves the international uniformity goal of Article 7, so that the rule legitimately may be applied under the Convention; ${ }^{12}$ and second, that the parol evidence rule addresses a problem governed, but left unresolved, by the Convention and conforms to general principles underlying the Convention, so that the rule may be applied to CISG contracts. Based on these two arguments, the article concludes that the Fifth Circuit's application of the parol evidence rule may well have been justified, whether or not the United Nations Convention on Contracts for the International Sale of Goods also applied.

\section{The parol evidence rule}

The parol evidence rule guides courts in the United States and other common law countries in their initial determination of the content of written

11 See Commentary on the Draft Convention on Contracts for the International Sale of Goods, Prepared by the Secretariat, 'UN Conference on Contracts for the International Sale of Goods' Article 6, committee 1, at 17-18, UN Doc A/Conf 97/19 (1980), in Documentary History, supra note 2, 407-08 ('National rules on the law of sales of goods are subject to sharp divergences in approach and concept. Thus, it is especially important to avoid differing constructions of the provisions of this Convention by national courts, each dependent upon the concepts used in the legal system of the country of the forum.'); MJ Bonell, 'Introduction' to Bianca and Bonell, supra note 2, 19 ('The Convention's main purpose is to bring about uniformity at a world-wide level in the law of international sales contracts. To this end it is ... important that its provisions be interpreted in the same way in various countries.'); Ackerman, supra note 2,535-36 ('[CISG] is a transnational law with a transnational legislative history. Thus, its interpretation must also be transnational.'); Flechtner, supra note 10,176 ('It is critical to the long term success of CISG that courts apply it from a perspective that transcends the purely domestic sales law concepts with which they are familiar.'). Strict uniformity is not possible, however, unless courts are willing to follow uncritically the court that first interprets each CISG provision, whether the court's interpretation is correct or not. When flawed interpretations arise, divergence in application of the Convention is clearly desirable. As John Honnold noted in speaking of the UCC, 'a carefully considered decision to differ from decisions in other [jurisdictions] probably provides a healthy opportunity for reconsideration of doubtful decisions - a value that can counterbalance some degree of loss in uniformity'. Care and Feeding, supra note 6,8 , note 7 .

12 But cf Uniform Application, supra note 6, 208-09 (treating 'the tendency to think that the words we see are merely trying ... to state the domestic rule we know so well' as a flawed approach to CISG interpretation). 
contracts. ${ }^{13}$ Unfortunately, the United States version of the rule is not uniform. It has both statutory and varied common law manifestations. The statutory version - found in the Uniform Commercial Code (UCC) ${ }^{14}$ - applies to contracts governed by Article 2 of that Code. Since both Article 2 and the Convention govern sale of goods contracts, ${ }^{15}$ the UCC version of the parol evidence rule is likely to apply to contracts covered by the Convention. ${ }^{16}$

Yet there may be instances when the common law parol evidence rule will apply to CISG contracts. ${ }^{17}$ The paradigm common law parol evidence rule, summarised in Restatement (Second) of Contracts, ${ }^{18}$ actually differs little from the statutory version. The basic operation of the two versions can thus be jointly outlined as follows. 19

13 Australia, for example, applies a version of the parol evidence rule. For an overview of the Australian parol evidence rule, see BK Grossman and MP Ellinghaus, 'Classification and Construction of Terms' 7 The Laws of Australia 7.4[5], 7.4[45]-[64] (JA Riordan (ed), 1993). Like the United States parol evidence rule, the prevailing version of the Australian parol evidence rule does not apply until the court determines that the written contract in question is complete. See id 7.4[53]. However, unlike the United States rule, the Australian rule directs the court to examine the parties' objective, rather than subjective, intent in determining whether the writing is exclusive. See id 7.4[51]. When the writing 'is apparently complete on its face', the 'presumption [is] that the parties intended [the] written document to be the sole and exclusive repository of their agreement'. Id 7.4[52]. If the writing is deemed complete and exclusive, "extrinsic evidence cannot be admitted to subtract from, add to, vary or contradict the language of the written instrument', Id 7.4[51]. If, on the other hand, the writing 'is only a partial ... record of the contract', '[e]vidence of additional terms is admissible'. Id 7.4[53]. In interpreting the writing, whether complete or not, '[e]xtrinsic evidence is [similarly] admissible as an aid to interpretation' but only when 'the language of the document ... [is] ambiguous ... and the evidence ... [is] of more than merely unilateral intention', Id 7.4[54]. Since the Australian parol evidence rule, in contrast to the United States rule, focuses on the objective rather than subjective intent of the parties and limits the use of extrinsic evidence in interpreting written contracts, the Australian rule is more likely displaced by the Convention. See infra notes 47 and 52 and text accompanying note 52. To the extent that the Australian parol evidence rule mirrors the United States rule, however, the arguments advanced in this article would also justify application of the Australian rule to CISG contracts. Nonetheless, this article's arguments are based on the United States version of the rule.

14 UCC ss 2-202 (1994).

15 UCC ss 2-102 ('[T]his Article applies to transactions in goods ...'); CISG, supra note 2, Article 1, S Treaty Doc no 9, 22, 19 ILM 672 ('This Convention applies to contracts of sale of goods ...'); Flechtner, supra note $10,162$.

16 The fact that the UCC parol evidence rule will apply to most contracts governed by CISG minimises any argument that the mere variety of parol evidence rules makes the rule inconsistent with CISG's goal of uniformity.

17 Flechtner, supra note 10,161-65 (arguing that the contract in Beijing Metals may have been governed by CISG even if, as the court found, it did not fall within the scope of UCC Article 2).

18 Although common law parol evidence rules undoubtedly vary among the States, this Article will only deal with one common law parol evidence rule, that summarised in the Restatement. See 2 Restatement (Second) of Contracts ss 209-18 (1979) [hereinafter Restatement 2d].

19 For more detailed, yet easy to follow, explanations of both the Restatement and UCC parol evidence rules, see JD Gordon III, 'Teaching Parol Evidence' (1990) Brigham Young University Law Review 647, 3; AL Corbin, Corbin on Contracts (St Paul, Minn: West Publishing Co, 1960), Chapter 26 (1960 and Supp 1994) offers a more comprehensive look at the parol evidence rule generally. JJ White and RS Summers, Handbook of the Law Under the Uniform Commercial Code ss 2-9 to 12 (2nd edn, 1980) provides more extensive discussion of the UCC parol evidence rule. 
In identifying the content of written contracts under the parol evidence rule, the court first asks whether the writing is partially integrated, ie whether the writing is final and complete as to some terms. ${ }^{20}$ The court next asks whether the writing is a complete integration - whether it contains the 'complete and exclusive' terms of the parties' agreement. ${ }^{21}$ Historically, courts used either of two approaches to determine, as required by the foregoing questions, whether a writing was a partial or complete integration. The Williston approach dictated that a court look primarily to the terms of the writing, as interpreted by a reasonable person in the circumstances, to determine whether an integration was intended. ${ }^{22}$ The Corbin approach instructed courts to look to all relevant evidence surrounding the agreement to decide whether the parties actually intended the writing to be complete and exclusive. ${ }^{23}$ Professor Corbin's approach has been adopted by both the Restatement and the UCC. ${ }^{24}$ Thus, modern courts applying the Restatement or

20 See 2 Restatement 2d, supra note 18, s 209(1) ('An integrated agreement is a writing or writings constituting a final expression of one or more terms of an agreement.'); id s 210(2) ('A partially integrated agreement is an integrated agreement other than a completely integrated agreement.'); UCC ss 2-202 (defining what the Restatement calls an integration as 'a writing intended by the parties as a final expression of their agreement with respect to such terms as are included therein').

21 See 2 Restatement $2 d$, supra note 18, s 210(1) ("A completely integrated agreement is an integrated agreement adopted by the parties as a complete and exclusive statement of the terms of the agreement.'); UCC ss 2-202(b) (describing what the Restatement terms a completely integrated agreement as a 'writing ... intended ... as a complete and exclusive statement of the terms of the agreement').

22 See $4 \mathrm{~S}$ Williston, A Treatise on the Law of Contracts s 633, 3rd edn (1961) 1014-15 ('It is generally held that the contract must appear on its face to be incomplete in order to permit parol evidence of additional terms.'); id 1016 ('If upon inspection and study of the writing, read, it may be, in the light of surrounding circumstances in order to insure its proper understanding and interpretation, it appears to contain the engagement of the parties, and to define the object and measure the extent of such engagement, it constitutes the contract between them, and is presumed to contain the whole of that contract.') (quoting Eighmie v Taylor, 98 NY 288, 294-95 (1885)); see also 1 Williston, supra, s 95, at 349-50 ('It is even conceivable that a contract may be formed which is in accordance with the intention of neither party. If a written contract is entered into, the meaning and effect of the contract depends on the interpretation given the written language by the court. The court will give that language its natural and appropriate meaning; and, if the words are unambiguous, will not even admit evidence of what the parties may have thought the meaning to be.').

23 See 3 Corbin, supra note 19, s 582, at 455 (In determining whether the parties intended their written agreement to be an integration, 'no relevant testimony should be excluded ... This is what the wiser courts, seeking justice in each case, have in truth been doing.'); see also AL Corbin, 'The Interpretation of Words and the Parol Evidence Rule', (1965) 50 Comell LQ 161, 161 (attacking the position 'that extrinsic evidence is not admissible to aid the court in the interpretation of a written contract (an integration) if the written words are themselves plain and clear and unambiguous').

24 See 2 Restatement 2d, supra note 18, ss $209 \mathrm{cmt} \mathrm{c,} 210 \mathrm{cmt} \mathrm{b}, 214$; UCC ss 2-202 cmt 1 . Under the Restatement: That a writing was or was not adopted as a completely integrated agreement may be proved by any relevant evidence. A document in the form of a written contract, signed by both parties and apparently complete on its face, may be decisive of the issue in the absence of credible contrary evidence. But a writing cannot of itself prove its own completeness, and wide latitude must be allowed for inquiry into circumstances bearing on the intention of the parties. 2 Restatement $2 \mathrm{~d}$, supra note 18, s $210 \mathrm{cmt}$ b. [UCC] section [2-202 likewise] rejects: (a) Any assumption that because a writing has been worked out which is final on some matters, it is to be taken as including all the matters agreed upon; (b) The premise that the language used has the meaning attributable to such language by rules of construction existing in the law rather than the meaning which arises out of the commercial context in which it was used; and (c) The requirement that a condition precedent ... 
UCC tests consider extrinsic evidence and focus on the parties' actual intent in determining whether a written contract is a partial or complete integration.

If the court determines that a writing is a partial integration, 'evidence of prior or contemporaneous agreements or negotiations is not admissible ... to contradict a term of the writing.' 25 Nevertheless, the partial integration 'may be explained or supplemented ... by evidence of consistent additional terms', ${ }^{26}$ unless 'the additional terms are such that, if agreed upon, they would certainly have been included in the document' 27 or are such 'as in the circumstances might naturally be omitted from the writing'.28 If the writing is deemed a complete integration, not even 'consistent additional terms' may be admitted to supplement the writing. ${ }^{29}$ Whether the writing is integrated or not, evidence of usage of trade, course of dealing, and course of performance is admissible to explain or supplement the agreement. ${ }^{30}$ Similarly, regardless whether the writing is integrated, evidence of '[a]greements and negotiations prior to or contemporaneous with the adoption of a writing are admissible ... to establish ... the meaning of the writing.' 31

... to the admissibility of the type of evidence specified in paragraph (a) is an original determination by the court that the language used is ambiguous. UCC ss 2-202 cmt 1; see also RA Hillman et al, Common Law and Equity Under the Uniform Commercial Code 3.05[2] (1985) ('Presumably under the Code, which seeks to enforce the parties' bargain in fact, [the] common law [four corners] approach has been displaced and extrinsic evidence will be admitted as a preliminary matter to determine the intentions of the parties on integration of their agreement. At any rate, this more liberal approach ... can be employed under the Code ...); White and Summers, supra note 19, ss $2-10$, at 79 ('Comment 3 to 2-202 may reject a four corners test.').

252 Restatement 2d, supra note 18, s 215; see also UCC ss 2-202 ('Terms ... set forth in a writing intended by the parties as a final expression of their agreement with respect to such terms as are included therein may not be contradicted by evidence of any prior agreement or of a contemporaneous oral agreement ...').

26 UCC ss 2-202; see also 2 Restatement 2d, supra note 18, s 216(1) ('Evidence of a consistent additional term is admissible to supplement [a partially] integrated agreement ...').

27 UCC ss 2-202 cmt 3.

282 Restatement $2 \mathrm{~d}$, supra note 18, s 216(2)(b).

29 Id s 216(1); UCC ss 2-202(b).

30 UCC ss 2-202; see 2 Restatement 2nd, supra note 18, s 222(3) (usage of trade); id s 223(2) (course of dealing) (It should be noted that Restatement ss 222 and 223 are not classed with the Restatement's parol evidence provisions.).

312 Restatement 2 d, supra note 18 , s 214 . The Restatement even allows 'extrinsic evidence [to] ... change the plain meaning of a writing'. Id $\mathrm{s} 212 \mathrm{cmt} \mathrm{b}$. The UCC, on the other hand, does not expressly admit parol evidence to aid in interpreting a writing. The UCC does, however, permit evidence of 'course of dealing or usage of trade ... or ... course of performance' to alter the meaning of the writing. UCC ss 2-202(a). In addition, '[c]onsistent with [the] definition of agreement [adopted in UCC ss 1-201(3)], the Code directs courts to admit extrinsic evidence liberally to determine the meaning of the words of the agreement ... [Like the Restatement, the Code thus displaces the common law plain meaning rule.' Hillman et al, supra note 24, 3.07[2][a][i], 3-34 (footnote omitted); see also Task Force of the ABA. Subcommittee on General Provisions, Sales, Bulk Transfers, and Documents of Title, Committee on the Uniform Commercial Code, An Appraisal of 1 March 1990, 'Preliminary Report of the Uniform Commercial Code Article 2 Study Group' (1991) 16 Delaware Joumal of Corporate Law 981, 1048 (suggesting that the revised UCC should clarify that the Code rejects the plain meaning rule in the interpretation of written contracts, though apparently advocating the rule "that extrinsic evidence is admissible if "relevant to prove a meaning to which the language is reasonably susceptible".') (quoting A Kemp Fisheries, Inc v Castle and Cooke, Inc, 852 F.2d 493, 495 (9th Cir 1988)). 
The parol evidence rule, then, focuses on the intention of the parties. Their intent, circumstantially manifest, determines whether their written agreement is an integration and defines the terms of their writing. The rule thus seeks to ensure that the parties' expectations and understandings will not be frustrated by extrinsic evidence. ${ }^{32} \mathrm{In}$ addition, the parol evidence rule is intended to effect at least three public policies: to protect 'written contracts against perjured or otherwise unreliable testimony of oral terms'; to exclude 'prior agreements which have been superseded by the [written contract] under a theory of merger'; and to motivate 'parties to put their complete agreement in writing' ${ }^{33}$ It may have been with these valuable policies in mind that the court in Beijing Metals applied the parol evidence rule to exclude evidence of contemporaneous oral agreements.

\section{Beijing Metals}

The facts of Beijing Metals are, in reality, of little relevance to this article, as its purpose is not to determine whether CISG governed the Beijing Metals contract $^{34}$ nor whether the Fifth Circuit reached an accurate conclusion under the parol evidence rule. This article assumes that the Beijing Metals contract fell within the Convention's scope and rather asserts, as explained above, that the court nonetheless justifiably found the parol evidence rule applicable. Because this conclusion is a proposition of law, it may be evaluated in isolation from the facts. Nevertheless, a brief overview of the Beijing Metals facts will illustrate the type of situation which gives rise to the legal issue with which this article deals.

American Business Center, Inc ( $\mathrm{ABC}$ ), an American marketer, ${ }^{35}$ entered into a deal with Beijing Metals and Minerals Import/Export Co (MMB), a manufacturing concern organised under the law of and doing business in the People's Republic of China, ${ }^{36}$ for the production and marketing of exercise equipment. ${ }^{37}$ In violation of the parties' modified agreement, $A B C$ 'refused to pay for approximately 27 shipments totalling more than $\$ 1.2 \mathrm{~m}$ '.38 $\mathrm{MMB}$ warned that it would cease scheduled shipments unless $A B C$ tendered a payment plan. ${ }^{39}$ Representatives of $\mathrm{ABC}$ and $\mathrm{MMB}$ met and negotiated a

32 See White and Summers, supra note 19 , ss $2-9$, at 76 ('AA] rule [such as UCC ss 2-202] ... is supposed to provide added assurance that the court will arrive at the truth as to disputed terms.').

33 Gordon, supra note 19, 647 (citing J Calamari and J Perillo, The Law of Contracts, 3rd edn (St Paul, Minn: West Publishing, 1987) 137).

34 Professor Flechtner argues that the contract in Beijing Metals may well have been governed by CISG. Flechtner, supra note 10,163. The court in Beijing Metals, however, did not decide the issue. See Beijing Metals, 993 F 2d, 1183 note 9.

35 Flechtner, supra note 10, 154; see also Beijing Metals, 993 F 2d, 1179-80.

36 Beijing Metals, 993 F 2d, 1179 note 1; Flechtner, supra note 10, 154.

37 Beijing Metals, 993 F 2d, 1179-80.

38 Id 1180.

39 Id. 
written agreement in which $A B C$ recognised its debt and committed to pay its obligation in specified installments. 40 Allegedly, the parties orally agreed to two additional terms: that MMB 'would ship goods to compensate for [previous] non-conforming and defective goods and shortages'; and that MMB would make new shipments on a 'document against acceptance' basis, giving ' $A B C 90$ days to pay' for shipments (D/A 90). ${ }^{41}$ After these negotiations had been concluded, $M M B$ informed $A B C$ that $M M B$ would not allow D/A 90 terms; $42 \mathrm{ABC}$ thereupon refused to comply with the agreement. ${ }^{43} \mathrm{MMB}$ sued to enforce the contract. ${ }^{44}$ In defence, $\mathrm{ABC}$ argued that MMB had breached at least one of the alleged oral terms. ${ }^{45}$ The district court held and the Fifth Circuit agreed 'that $A B C$ [was] barred by the parol evidence rule from introducing extrinsic evidence to alter the terms of the written agreement' 46 Thus, against a claim of oral alteration, the payment agreement stood, to ABC's detriment. Had the parol evidence rule not been applied, the case's outcome may well have been different. ${ }^{47}$

\section{Justifying the court's holding}

Professor Flechtner takes issue with the Beijing Metals holding, arguing that the parol evidence rule is inconsistent with CISG because "the Convention rejects any special methodology [such as the parol evidence rule] for determining the parties' intent as to the effect of a writing'.48 Professor Flechtner seeks support for this conclusion from CISG Articles 7(1) and 8(3)

40 Id.

41 Id.

42 Id.

43 Id 1181.

44 Id.

45 Id 1182.

46 Id 1184.

47 See Flechtner, supra note 10, 165 (arguing that if the payment agreement in Beijing Metals fell 'within the scope of CISG ... the Fifth Circuit should have applied the Convention's approach to parol evidence questions - with results likely to differ from those the court obtained by applying the Texas common law parol evidence rule').

48 Id 158. In reaching this conclusion, Professor Flechtner essentially concedes that, because the modern parol evidence rule admits extrinsic evidence to guide the interpretation of written contracts, Article 8(3) is consistent with the parol evidence rule when the rule is applied to interpretation. See Flechtner, supra note 10, 157-58; see also Brand and Flechtner, supra note 10, 252 ('Evidence of prior negotiations going to the interpretation of a written contract is admissible under CISG just as it is under the parol evidence rule.'). Compare 2 Restatement 2d, supra note 18, 212 illus 4 (if buyer and seller orally agree that buy means sell and sell means buy, their oral agreement will control the interpretation of their written contract) with Bianca and Bonell, supra note 2, 98 (Under Article $8(1)$, if seller and buyer agree 'to show a price of 50,000 in the contract, rather than the true price of $100,000, \ldots$ their contract will be interpreted according to their common understanding, 100,000 not $\left.50,000^{\prime}\right)$. This Article thus assumes that the application of the parol evidence rule to interpretive questions may be viewed as an implementation of the Convention and focuses on establishing that the rule may also be seen as an application of CISG when the rule is used to determine 'the parties' intent as to the effect of [their] writing.' Flechtner, supra note 10, 158. 
and, in particular, from the fact that the Convention 'lack[s] ... any provision ... affording special treatment to parol evidence questions' ${ }^{49}$ In as much as Professor Flechtner's conclusion is based on the absence of a CISG parol evidence provision, his conclusion is incorrect. If the Convention did give special treatment to the parol evidence issue, that treatment would either support or displace application of the parol evidence rule. When the Convention does not give special treatment to a rule of law, however, the rule is not automatically displaced. Instead, the rule's fate depends on whether the Convention settles issues within the rule's scope against the rule, and if the Convention does not settle those issues, on whether the rule conforms with the general principles of the Convention. ${ }^{50}$ This section argues first that CISG Article 8 settles questions regarding both the determination of the parties' intent as to the effect of their writing and the admissibility of extrinsic evidence consistent with the parol evidence rule, so that courts may apply the parol evidence as an expression of Article 8. This initial argument is buttressed by the fact that the parol evidence rule satisfies the international uniformity mandate of Article 7(1). ${ }^{51}$ Second, this section alternatively contends that CISG governs, but does not expressly settle, parol evidence issues and that the parol evidence rule conforms 'with the general principles [of CISG]', so that, consistent with Article 7(2), the parol evidence rule may be applied to CISG contracts. 52

\section{The parol evidence rule: an application of Article 8 consistent with the international mandate of Article 7}

\section{The parol evidence rule as an application of Article 8}

Article 8 essentially dictates that, in interpreting the effect of a written contract, the court should focus on each party's subjective intent if that intent was known by or 'could not have been' unknown to the other party; 53 otherwise the court should look to the parties' objective intent, ie 'to the understanding that a reasonable person of the same kind as the other party would have had in the same circumstances' ${ }^{54}$ More importantly, in assessing the parties' subjective intent or the understanding of a similarly-situated reasonable person, the court is to give 'due consideration ... to all relevant

49 Flechtner, supra note 10, 158.

50 See CISG, supra note 2, Article 7(2), S Treaty Doc no 9, at 23-24, 19 ILM 673.

51 See CISG, supra note 2, Article 7(1), S Treaty Doc no 9, at 23, 19 ILM 673.

52 See CISG, supra note 2, Article 7(2), S Treaty Doc no 9, at 24, 19 ILM 673.

53 CISG, supra note 2, Article 8(1), S Treaty Doc no 9, at 24, 19 ILM 673.

54 Id Article 8(2); see 'Commentary on the Draft Convention on Contracts for the International Sale of Goods, Prepared by the Secretariat, UN Conference on Contracts for the International Sale of Goods Article 7', cmt 4, 18, UN Doc A/Conf 97/19 (1980), in Documentary History, supra note 2, 408 (explaining the initial subjective and default objective inquiries mandated by a predecessor of Article 8). 
circumstances of the case including the negotiations, any practices which the parties have established between themselves, usages and any subsequent conduct of the parties'.55 Thus, Article 8 instructs courts to consider circumstantial parol evidence in interpreting the effect of written contracts.

At first glance, then, the parol evidence rule appears inconsistent with Article 8. If the modern version of the rule did prevent consideration of all parol evidence, or if it embraced Professor Williston's limited approach to determining integrationist intent, 56 the rule would clearly be inconsistent with Article 8.57 If inconsistent, the rule would just as clearly be displaced by CISG. 58 The legislative history and language of Article 8, however, indicate that the parol evidence rule may well be viewed as an expression of Article 8 .

(a) The legislative history of Article 8

Article 8 underwent significant modification as it progressed through the legislative process that led to its incorporation into the Convention..$^{59}$ Early in its formulation, the future Article 8(3) read:

The intent of the parties or the intent a reasonable person would have had in the same circumstances ... [may] [is to] be determined in the light of the circumstances of the case including the [preliminary] negotiations, any practices which the parties have established between themselves, any

55 CISG, supra note 2, Article 8(3), S Treaty Doc no 9, 24, 19 ILM 673.

56 See supra note 22 and accompanying text.

57 The legislative history of Article 8 makes clear that courts applying the Convention should consider extrinsic evidence in identifying the terms and effect of a contract regardless whether the contract is embodied in a writing or whether the writing appears clear on its face. See 'Report of the Working Group on the International Sale of Goods on the Work of its Eighth Session' [1977] VIII UN Comm'n Int'l Trade L YB 155, 168, at 86, 87, UN Doc A/CN9/Ser A/1977, in Documentary History, supra note 2, 287, 288 (documenting that a provision that was part of a predecessor to Article 8 and that required the circumstances listed in Article 8(3) 'to be considered, even though they have not been embodied in writing or in any special form' was deleted, because it was deemed unnecessary, likely because the predecessor to Article 8 already made this principle clear); 'Commentary on the Draft Convention on Contracts for the International Sale of Goods, Prepared by the Secretariat, UN Conference on Contracts for the International Sale of Goods' Article 7, cmt 5, 6, 18, UN Doc A/Conf 97/19 (1980), in Documentary History, supra note 2, 408 ('In determining the intent of a party or the intent a reasonable person would have had in the same circumstances, it is necessary to look first to the words actually used or the conduct engaged in. However, the investigation is not to be limited to those words or conduct even if they appear to give a clear answer to the question ... In order to go beyond the apparent meaning of the words or the conduct by the parties, Article [8](3) states that "due consideration is to be given to all relevant circumstances of the case".') (quoting a draft version of Article 8(3)).

58 See United States Const Article VI, cl 2 ('[A]ll treaties made, or which shall be made, under the authority of the United States, shall be the supreme law of the land; and the judges in every State shall be bound thereby, any thing in the Constitution or laws of any State to the contrary notwithstanding.'); see also Domesticating Intemational Law, supra note 10, 43 ('As a treaty made under the authority of the United States, the Convention is the 'supreme Law' of the United States and would prevail over conflicting State law.') (quoting United States Const Article VI, cl 2).

59 Compare eg 'Article 14 of the Draft Convention on the Formation of Contracts for the International Sale of Goods as Approved or Deferred for Further Consideration by the Working Group on the International Sale of Goods at Its Eighth Session' [1977] VIII UN Comm'n Int'1 Trade L YB 90, UN Doc A/CN9/Ser A/1977, in Documentary History, supra note 2, 291, with the version of Article 8 adopted by the Convention, CISG, supra note 2, Article 8, S Treaty Doc no 9, 24, 19 ILM 673. 
conduct of the parties subsequent to the conclusion of the contract, usages ... and any applicable legal rules for contracts of sale' ${ }^{60}$

The italicised clause may well have accommodated application of the parol evidence rule in determining the subjective or objective intent of the parties, as the parol evidence rule is a legal rule that applies to contracts generally and is made applicable to 'contracts of sale' specifically through ss 2-202 of the UCC. ${ }^{61}$ As Article 8 evolved, the clause was deleted, not because it was inconsistent with the principles of Article 8, but because it was deemed 'unnecessary' ${ }^{62}$ That legal rules applicable to sales contracts - at least those rules consistent with Article 8 - would continue to apply in determining the parties' intent after the enactment of Article 8 may thus have seemed apparent to the working group. Although the point is not as apparent to commentators today, this bit of legislative history suggests that the Convention may well accommodate the parol evidence rule, particularly since the rule is essentially an expression of Article $8 .{ }^{63}$

(b) The language of Article 8

The text of Article 8 supports the conclusion that the parol evidence rule may be seen as an expression of that provision. As explained above, Article 8 instructs courts to determine the effect of a contract according to the parties' subjective intent, or failing that, according to their objective intent. 64 Further, Article 8 directs courts to look 'to all relevant circumstances' in determining that intent. 65 The parol evidence rule implements these instructions. It requires the court to determine whether a writing is completely or partially integrated

60 'Report of the Working Group on the International Sale of Goods on the Work of Its Eighth Session' [1977] VII UN Comm'n Int'l Trade L YB 155, 86, UN Doc. A/CN9/Ser A/1977, in Documentary History, supra note 2, 287 (emphasis added - brackets in original) (quoting a draft text of Article 14(4) of the 1964 Hague Uniform Law on the Formation of Contracts for the International Sale of Goods, which was under revision).

61 Of course, this clip of legislative history is not determinative. While the plain language of the italicised clause certainly could accommodate application of the parol evidence rule, the clause may well have had a different meaning to members of the working group. At the least, the clause raises doubts as to whether Article 8 was meant categorically to displace application of the parol evidence rule. But see 'UN Conference on Contracts for the International Sale of Goods' 1st committee, 6th meeting, 51, at 262, UN Doc A/Conf 97/19 (1980), in Documentary History, supra note 2, 483. Yet, according to the Australian representative to the first committee, no provision similar to Article 8 "existed in the common law countries, due to the prohibition of "parol evidence", a rule which should be amended in respect of international trade'. Id. The Australian representative's comment indicates that he felt that a blanket prohibition on parol evidence was inappropriate in international trade and would be displaced by the later draft of Article 8 that he was considering. However, because the modern version of the parol evidence rule does not exclude all parol evidence, see supra notes $25-30$ and accompanying text, the rule is not automatically inconsistent with or precluded by Article 8.

62 'Report of the Working Group on the International Sale of Goods on the Work of Its Eighth Session' [1977] VIII UN Comm'n Int'l Trade L YB 166, 87, UN Doc A/CN9/Ser A/1977, in Documentary History, supra note 2, 288.

63 But see supra note 10.

64 See supra notes 53-54 and accompanying text.

65 CISG, supra note 2, Article 8(3), S Treaty Doc no 9, at 24, 19 ILM 673. 
by looking to the intent of the parties, ${ }^{66}$ intent that may be indicated "by any relevant evidence'. ${ }^{67}$ Initially at least, the parol evidence rule appears a mere application of Article 8.68 Yet the rule may require the use of what Professor Flechtner calls 'a distinct set of tests and procedures for ascertaining ... the parties [intent]' ${ }^{69}$ '[T] he Convention,' he contends, clearly 'rejects any special methodology for determining the parties' intent as to the effect of a writing. 70

Professor Flechtner's conclusion is not immune from dispute, however. The language of Article 8 indicates that in determining intent "due consideration is to be given to all relevant circumstances of the case including the negotiations, any practices which the parties have established between

66 See supra note 24.

672 Restatement 2d, supra note $18, \mathrm{~s} 210 \mathrm{cmt} \mathrm{b}$.

68 See Brand and Flechtner, supra note 10,251 ("At bottom, the parol evidence rule is merely a particular application of the fundamental "intent principle" of contract law ... Far from invalidating such a rule, CISG Article 8(3) emphasises the importance of the parties' intent ...'); see also Unifom Law', supra note 2, s 110, at 171 ('The Convention ... would not interfere with the decision to exclude from a jury evidence of prior or contemporaneous agreements if ... "the court finds" (after giving due consideration to all relevant circumstances) that the writing was "intended also as a complete and exclusive statement of the terms of the agreement".') (quoting UCC ss 2-202) (emphasis in Uniform Law).

69 Flechtner, supra note 10,158. Specifically, Professor Flechtner objects to the presumption that a writing is intended as an integration, see 2 Restatement 2 d, supra note $18, s 209(3)$, and the rule that consistent additional terms may be proved to supplement a partial integration only if those terms might reasonably have been omitted or, if adopted by the parties, would definitely have been recorded in the writing, see supra notes 27-28 and accompanying text. See Flechtner, supra note 9, 159-60. In response to Professor Flechtner's concerns, it should be noted that the presumption that a writing is intended as an integration is only explicit in the Restatement version of the parol evidence rule. See 2 Restatement 2d, supra note 18, s 209(3). Any conflict with Article 8 that this presumption might present is therefore marginalised by the fact that the UCC version of the parol evidence rule will normally apply to sales contracts governed by CISG. See supra notes $15-16$ and accompanying text. Further, the presumption acts as a default, providing the court direction when the evidence does not indicate that the intent of the parties or of a reasonable person is contrary to the written agreement. See id s $209 \mathrm{cmt} c$ (stating that '[w]hether a writing has been adopted as an integrated agreement is ... to be determined in accordance with all relevant evidence' and indicating that the presumption of integration applies only 'in the absence of contrary evidence'). In such situations, the Convention does not indicate what the court should do, so the court may legitimately look to domestic law for guidance, see infra notes $90-91$ and accompanying text, and may certainly settle on a default such as the parol evidence rule which would appear internationally acceptable in these situations and which is consistent with the general principle of the Convention, recognised in Article 12, that contracting States may protect their interests in written agreements, see infra part IV.B.4. As to Professor Flechtner's objection to the consistent additional terms rule, Professor Fletchner concedes that at least the Texas version of the rule 'might [by itself] be an unobjectionable method for delermining whether alleged terms form a transaction separate from the one integrated into a writing, and thus outside the intended preclusive scope of the integration'. Flechtner, supra note 9,160. Professor Flechtner's main objection is that the rule is so 'encrusted by purely domestic precedent' that '[i]t would now be virtually impossible for a United States court to use the test in a manner that was genuinely international and that would promote uniformity with decisions by courts of other contracting States' as Article 7(1) intends. Id. That a rule is of domestic origin is not reason enough to reject it, however. If the rule is not displaced by the Convention, is consistent with the Convention, and promotes international uniformity in some way, the rule arguably remains valid under the Convention. See supra note 49 and accompanying text.

70 Flechtner, supra note 9, 158; see also Brand and Flechtner, supra note 10, 251 (like the parol evidence rule, 'CISG Article 8(3) emphasises the importance of the parties' intent - although clearly the Convention does not adopt the somewhat bizarre and abstruse methods for determining intent associated with the parol evidence rule.'). 
themselves, usages and any subsequent conduct of the parties' ${ }^{71}$ Intent, then, is controlling; parol evidence must only be given 'due consideration' under the Convention. The parol evidence rule implements Article 8 by making intent the touchstone in determining whether an integration exists and consequently whether the parol evidence rule should apply to protect that integration. Arguably, at least, the parol evidence rule also applies the instructions of Article 8 by giving 'due consideration ... to all relevant circumstances of the case'. ${ }^{72}$ Indeed, under the parol evidence rule, the judge considers 'all relevant evidence' in determining the parties' intent to integrate. ${ }^{73}$ In addition, the rule admits to the fact finder evidence of usage of trade, course of dealing, and course of performance to interpret and augment the writing. ${ }^{74}$ And finally, if the writing is only partially integrated, the rule also generally admits 'evidence of consistent additional terms' to explain or supplement the writing. ${ }^{75}$

True, the parol evidence rule applies some objective tests or presumptions, ${ }^{76}$ but Article 8 itself was intended to be less subjective than might be supposed. The drafters of Article 8 explicitly tempered its subjective focus by changing one of the triggers for application of the subjective test from 'ought to have known' to 'could not have been unaware what [the] intent was' ${ }^{77}$ As a result, the subjective prong of Article 8 will apply in few cases. ${ }^{78}$

In sum, the parol evidence rule may be said to comply with the express terms and legislative intent of Article 8. The question thus becomes whether the parol evidence rule, as an application of Article 8, is consistent with the instruction of Article 7(1) that:

71 CISG, supra note 2, Article 8(3), S Treaty Doc no 9, 24, 19 ILM 673.

72 Id.

732 Restatement $2 \mathrm{~d}$, supra note 18 , s $209 \mathrm{cmt}$ c; see supra note 24 and accompanying text.

74 See supra note 30 and accompanying text.

75 UCC ss 2-202(b); see supra notes 26-28 and accompanying text. Of course, the parol evidence rule also admits all relevant evidence to aid in the interpretation of the writing. See supra notes 31 and 48 and accompanying text.

76 See supra notes 27-28 and accompanying text.

77 'Report of the United Nations Commission on International Trade Law on the Work of its Eleventh Session' [1978] IX UN Comm'm Int'1 Trade L YB 34, at 34, UN Doc $N / C N 9 / S e r ~ A / 1978$, in Documentary History, supra note 2,368; id 39 ("II]n paragraph (1) the expression "could not have been unaware what that intent was" replaced the expression "ought to have known what that intent was". This reflected the concern expressed in the Commission that the previous version of paragraph (1) contained too subjective a test.') (quoting provisions in the evolving drafts of what became Article 8).

78 Uniform Law, supra note 2, s 107, at 164-65 ('[B]ecause of the practical barriers to proving identity between the intent of the two parties ... most problems of interpretation will be governed by paragraph (2) which follows the "objective" approach ...'); P Volken, 'The Vienna Convention: Scope, Interpretation, and Gap-filling', in International Sale of Goods, supra note 2, 19, 4. (The subjective prong of Article 8 'requires a qualified addressee, for it presupposes that the [addressee] knew or could not have been unaware of the speaker's intent. In most cases it cannot be proved that one is dealing with a qualified addressee'. Consequently, Article 8 provides a back-up objective standard.) 
[i]n the interpretation of this Convention, regard is to be had to its international character and to the need to promote uniformity in its application and the observance of good faith in international trade. 79

Professor Flechtner, of course, argued that it was not. ${ }^{80}$ If, in spite of Professor Flechtner's argument, the parol evidence rule may be said to be both consistent with Article 8, as illustrated, and consistent with the international thrust of Article 7(1), then the holding in Beijing Metals that the parol evidence rule applies to contracts governed by the Convention is justifiable. It is therefore to a discussion of the parol evidence rule's consistency with Article 7(1) that this article turns.

\section{The parol evidence rule, promoting international uniformity under Article 7(1)}

While many have argued that the parol evidence rule is inconsistent with the uniformity of application sought by CISG, and while the rule is certainly attached to domestic precedent, the rule promotes uniformity and therefore satisfies the demands of Article 7(1) in at least two senses. ${ }^{81}$ The parol evidence rule requires the judge, not the jury, to determine, at least initially, the effect the parties intended for their writing. ${ }^{22}$ CISG 'has ... adherents from each economic and legal system of the world'; 83 these systems also assign the

79 CISG, supra note 2, Article 7(1), S Treaty Doc no 9, 23, 19 ILM 673.

80 See Flechtner, supra note 10, 158-59.

81 But $c f$ Bianca and Bonell, supra note 2, 74 (arguing that "to have regard to the ["]international character["] of the Convention ... implies the necessity of interpreting its terms and concepts autonomously, ... not by referring to the meaning which might traditionally be attached to them within a particular domestic law').

82 See 2 Restatement 2d, supra note 18, ss 209 (2), 210(3) ('Whether there is an integrated agreement' as well as '[ $w \mid$ hether an agreement is completely or partially integrated is to be determined by the court as a question preliminary to determination of a question of interpretation or to application of the parol evidence rule.'. While the Restatement characterises the court's determination as to the effect of a writing as preliminary to the application of the parol evidence rule, the determination may well be considered the threshold inquiry mandated by and therefore part of the rule.); UCC ss 2-202 cmt 3 (indicating that the court determines whether a writing was meant to be an integration); White and Summers, supra note 19, ss 2-9, 77 (outlining the allocation of adjudicatory power between the judge and jury under the UCC parol evidence rule); see also Uniform Law, supra note $2, s 110,171$ ("[The parol evidence rule has its greatest significance in restricting the role of juries in the field of contract interpretation.'); Brand and Flechtner, supra note 10, $252 \mathrm{n} 47$ ('From another perspective, the parol evidence rule seems primarily a rule of procedure - ie it requires the judge rather than the jury to make the factual determination whether the parties intended to discharge prior or contemporaneous agreements that were not included in a writing. Clearly nothing in Article 8(3) or the rest of the Convention overrules this procedural aspect of the parole evidence rule.') (citation omitied); Domesticating Intemational Law, supra note 10, 57 ('To the extent that [the UCC parol evidence rule] merely allocates the task of determining the parties' intent between judge and jury, it is not inconsistent with the Convention.').

83 Care and Feeding, supra note 6, 1; see generally SG Zwart, "The New International Law of Sales: A Marriage Between Socialist, Third World, Common, and Civil Law Principles' (1988) 13 North Carolina Joumal of Intemational Law and Commercial Regulation 109, 114-23 (summarising the Eastern bloc and developing country perspectives on CISG and discussing sensitive issues for Eastem bloc, developing, common law, and civil law jurisdictions during the formation of the Convention). 
interpretation of contracts to judges. ${ }^{84}$ The parol evidence rule thus brings United States courts into greater procedural harmony with courts of other nations in applying the Convention. ${ }^{85}$

In addition, because judges are more likely than jurors to consider the international character of the Convention, the parol evidence rule increases the likelihood that United States courts will reach more internationally-uniform results. Thus, although the rule may involve United States courts in a mechanically different inquiry in applying Article $8,{ }^{86}$ the rule allows American courts both to comply with the substance of Article 8, as discussed above, and to achieve more uniformity of result with courts of other countries. By reducing the involvement of juries, the parol evidence rule actually advances the Convention's uniformity goal. The parol evidence rule may thus be applied under the Convention, as the court concluded in Beijing Metals, as an appropriately international application of Article 8.

\section{The parol evidence rule in harmony with general principles of the Convention}

This article has argued that the parol evidence rule is justifiably applied to contracts governed by CISG, in part, because the rule is an implementation of Article 8. That argument depends on the premise that the rule satisfactorily gives 'due consideration ... to all relevant circumstances' in determining the parties' intent, as mandated by Article 8.87 Of course, it may be argued that the parol evidence rule does not satisfy this requirement. The Convention itself

84 See G Casper and H Zeisel, 'Lay Judges in the German Criminal Courts' (1972) 1 J Legal Stud 135, 135-36 ('The jury has thus maintained its position mainly in the orbit of the common law ... but more than anywhere in ... the United States, where trial by jury is standard in both criminal and civil cases. More than $90 \%$ of the world's criminal jury trials, and nearly all of its civil jury trials, take place in the United States ...'); Herbert J Liebesny (1981) Foreign Legal Systems: A Comparative Analysis 312 ('There is no jury trial in civil cases in France, or for that matter in other civil law countries.'); Max Rheinstein, 'Comparative Law - its Functions, Methods and Usages' (1968) 22 Arkansas Law Review and Bar Association Joumal 416, reprinted in JH Merryman and DS Clark (1978) Comparative Law: Western European and Latin American Legal Systems I1, 17 ('In civil law countries trial by jury is a rare exception in criminal cases and never used at all in civil matters.').

85 This increased uniformity is accomplished by the parol evidence rule alone and not by the Convention, for the Convention does not affect contracting States' allocation of adjudicatory power between judge and jury. Uniform Law, supra note 2, s 110, 171.

86 This mechanically-different inquiry may have been fashioned to deal with the challenges of jury trial and to bring jury trials into greater harmony with bench trials. See $M$ Rheinstein, 'Comparative Law - its Functions, Methods and Usages' (1968) 22 Arkansas Law Review and Bar Association Joumal 416, reprinted in Merryman and Clark, supra note 84, 11, 17 ('Jury trial has ... been the cause for the development of a special law of evidence, which ... is one of the most complicated.'); Liebesny, supra note 84, 312 ('There is no jury trial in civil cases in France, or ... in other civil law countries. Evaluation of the evidence thus is exclusively in the hands of trained judges and the rules are less strict than in common law.').

87 CISG, supra note 2, Article 8(3), S Treaty Doc no 9, 24, 19 ILM 673. 
does not 'expressly settle' what constitutes due consideration. 88 The Convention dictates, however, that issues such as this, which are governed but not expressly settled by the Convention, 'are to be settled in conformity with the general principles on which [the Convention] is based or, in the absence of such principles, in conformity with the law applicable by virtue of the rules of private international law' 89 While favouring the Convention's general principles over domestic law, this provision nonetheless permits courts to turn to domestic law in the first instance. ${ }^{90}$ When a gap appears, the provision mandates resolution 'in conformity with' the Convention's underlying principles. ${ }^{91}$ Thus, if a domestic law conforms to the principles of the Convention, that law may provide the rule of decision, just as it may when no

88 CISG, supra note 2, Article 7(2), S Treaty Doc no 9, at 23-24, 19 ILM 673. It may, of course, be argued that characterisation of the 'due consideration' issue as a gap results from a sceptical, common law perspective inconsistent with the Convention's international focus. See $P$ Volken, 'The Vienna Convention: Scope, Interpretation, and Gap-filling', in International Sale of Goods, supra note 2, 19, 43 (quoting U Huber, Der UNCITRAL-Entwurf eines Uebereinkommens uber internationale Warenkaufvertrage, in Rabels Z 432-33 (1979)). According to Ulrich Huber, 'The question of what has to be considered as a gap under the Convention, cannot be answered on a mere rational basis. Someone who has a positive stand towards the Convention will discover but few gaps. On the other hand, if a person is sceptical about the international unification of the Sales Law, he [or she] will every now and then run into unsettled questions. In addition, a common law jurist, because of his [or her] legal tradition, will probably tend towards a more restrictive interpretation of the Convention and its provisions. Thus, he [or she] might more often be confronted with a gap, than would be a civil law jurist. Civil law jurists are more frequently used working with generally framed, systematically conceived legal codes. Out of this experience, they are more readily prepared to solve unsetled questions or to fill gaps by referring to the general principles contained in the code itself.' Id; see also Uniform Application, supra note 11, 210 (explaining that common law judges naturally will be more prone than civil law judges to find gaps in and less prone to extract underlying principles from CISG). While common law lawyers may be more prone to find gaps in the Convention, the fact that the Convention defines gaps as matters governed but not expressly settled by the Convention, see Bianca and Bonell, supra note 2,75, 76, certainly provides a basis for that proneness.

89 CISG, supra note 2. Article 7(2), S Treaty Doc no 9, 23-24, 19 ILM 673. For a brief summary of the legislative history of Article 7, see P Winship, 'Private International Law and the UN Sales Convention' (1988) 21 Comell Int'l $L J$ 487, 509-15 [hereinafter Private International Law]. The general principles of which Article 7(2) speaks may be found in 'examination of [the] various specific provisions of the [Convention]' and of the Convention's legislative history. 'Working Group on the Intemational Sale of Goods; Report on the Work of the Second Session, 7-18 Dec 1970' [1971] II UN Comm'n Int'l Trade L YB 132, at 62, UN Doc A/CN9/Ser A/1971, in Documentary History, supra note 2, 68 (speaking of a predecessor of Article 7(2) found in the Uniform Law on Sales); see also 'Report of the Working Group on the International Sale of Goods, First Session, 5-16 January 1970' [1970] I UN Comm'n Int'l Trade L YB 59, at 182, UN Doc A/CN9/Ser A/1970, in Documentary History, supra note 2, 20 (referring to the Uniform Law on Sales and explaining that ' $[t]$ he general principles ... are the general ideas which inspired the Uniform Law... [and that t]hese principles can be gathered from the provisions of the Uniform Law, from the legislative history of the 1964 Hague Convention [which finalised the Uniform Law on Sales, see Documentary History, supra note 2, 1,] and from commentary on the Uniform Law.').

90 But see 'Report of the Working Group on the International Sale of Goods, First Session, 5-16 January 1970' [1970] I UN Comm'n Int'l Trade L YB 59, at 182, UN Doc A/CN9/Ser A/1970, in Documentany Histon, supra note 2, 20. By directing recourse to general principles, the drafters of a predecessor to Article $7(2)$ 'wished to free judges from having to look to national law for the solution of these problems, an avenue that would lead to disunity'. Id. When domestic laws, like the parol evidence rule, conform to general principles and enhance uniformity, however, the drafters' concern over disunity resulting from national law disappears or, ironically, may be best addressed through application of the domestic law.

91 CISG, supra note 2, Article 7(2), S Treaty Doc no 9, 23-24, 19 ILM 673. 
general principles apply. ${ }^{92}$ It is important that the domestic law satisfy the international uniformity mandate of Article 7(1). In sum, in the possibly rare situations when a domestic law both satisfies the uniformity mandate and conforms with other general principles underlying Convention, that domestic law may be used to resolve issues left unsettled by the Convention.

The parol evidence rule is such a law. The Beijing Metals holding - that the parol evidence rule applies to contracts governed by the Convention - may thus be justified on this separate ground: that the parol evidence rule is a domestic law that resolves the unsettled issue of what constitutes 'due consideration' in determining parties' intent, heeds the international uniformity directive of Article 7(1), and conforms with general principles underlying the Convention. ${ }^{93}$ The parol evidence rule clcarly provides a solution to the 'due consideration' problem. As noted above, the parol evidence rule is also arguably consistent with the principle of international uniformity embodied in Article 7(1). ${ }^{94}$ Finally, the parol evidence rule is consistent with the good faith guideline of Article 7 and the general principles manifest in Articles 6 and 29; 9; 12 and 98.

\section{Article 7}

Aside from directing interpreting courts to consider the international character and uniformity goal of the CISG, Article 7 instructs courts to interpret the Convention with regard 'to the need to promote ... the observance of good faith in international trade'. ${ }^{95}$ This good faith paradigm 'was intended to direct

92 See id; cf Private International Law, supra note 89, 530 (relying on the 'in conformity' language of Article 7(2) to suggest that courts need not turn to actual domestic law, but only to rules consistent with domestic law, when general principles fail to resolve issues governed by the Convention). But cf Diederichsen, supra note 6,181. Diederichsen contends that "[r]eliance upon domestic rules of conflict of law [, though possibly the only practical alternative when an issue is not resolved by CISG,] ... does not advance the uniform interpretation and application of the Convention as required by CISG, Article 7'. Id. While Diederichsen's assertion may often be true, domestic rules like the parol evidence rule that actually enhance the uniform application of the Convention and that are otherwise consistent with the Convention's underlying principles satisfy the mandates of Article 7 and therefore may apply to CISG contracts. See supra part IV.A.2; infra part IV.B.I-4.

93 Alternatively, it may be argued that the principles underlying the Convention do not indicate what constitutes 'due consideration', so that the court may turn to the domestic law applicable under conflicts rules for an answer. See CISG, supra note 2, Article 7(2), S Treaty Doc no 9, 23-24, 19 ILM 673 ("IT]n the absence of [relevant general] principles, [matters governed but unresolved by CISG are to be settled] in conformity with the law applicable by virtue of the rules of private international law.'). Assuming that United States domestic law governs, the parol evidence rule would be the proper rule to apply, particularly since the rule is consistent with general principles underlying CISG See infra part IV.B.1-4.

94 See supra part IV.A.2.

95 CISG, supra note 2, Article 7(1), S Treaty Doc no 9, 23-24, 19 ILM 673. While some representatives argued that the good faith requirement should apply only to the contracting parties, see 'UN Conference on Contracts for the International Sale of Goods Ist Committee, 5th meeting', 41, 43, 44, at 257-58, UN Doc A/Conf 97/19 (1980), in Documentary History, supra note 2, $478-79$, the good-faith requirement actually adopted in Article 7(1) applies to the interpretation of the Convention as well, see id 47, 49, 52, 54, 55, 258, in Documentan Histoni, supra note 2, 479; see also $P$ Volken, 'The Vienna Convention: Scope, Interpretation, and Gap-filling, in Intemational Sale of Goods', supra note 2,19,42. (The good faith requirement 'was finally accepted as a general interpretation rule to be applied to the Convention as a whole'.) 
the attention of the courts in resolving disputes to the fact that the acts and omissions of the parties must be interpreted in the light of the principle that they observe good faith in international trade' ${ }^{96}$ The parol evidence rule is consistent with this good-faith perspective. That rule prevents parties from entering final, exclusive agreements and then seeking to escape or unilaterally alter unfavourable terms by pleading in bad faith the existence of prior or contemporaneous oral terms. ${ }^{97}$ The parol evidence rule thus conforms to, indeed enforces, the good faith principle made explicit in Article 7.

\section{Articles 6 and 29}

The parol evidence rule also comports with the principle of party autonomy embodied in Articles 6 and 29.98 Article 29, in derogation of the provision in

96 'Report of the United Nations Commission on International Trade Law on the Work of its Eleventh Session' [1978] IX UN Comm'n Int'] Trade L YB 57, at 36, UN Doc A/CN9/Ser A/1978, in Documentary History, supra note 2, 370. While some view the good faith requirement as an interpretive guideline only, see Uniform Law, supra note 2, s 94, 147, Professors Bianca and Bonell conclude that the better view is that the requirement also applies to the contracting parties. Bianca and Bonell, supra note 2,84. Whether the good faith requirement of Article 7(1) is deemed to apply only to interpretation or also to the parties, good faith appears to be a general principle of the Convention. See $i d 85$. As such,the good faith requirement may govern the parties when their dispute is covered but not expressly resolved by the Convention, for then general principles become rules of decision. See id.

97 See Gordon, stupra note 19, 647.

98 See 'UN Conference on Contracts for the International Sale of Goods, 7th plen mtg', 25, at 206, UN Doc A/Conf 97/19 (1980), in Documentary History, supra note 2, 741 (In explaining his rejection of a proposal to alter present Article 29, the Canadian representative commented that 'the Convention ... was based squarely on the doctrine of the autonomy of the will of the parties'); Working Group on the International Sale of Goods; 'Report on the Work of the Second Session, 7-18 Dec 1970', [1971] II UN Comm'n Int'1 Trade L YB 46, at 55, UN Doc A/CN9/Ser A/1971, in Documentary Histary, supra note 2, 61 (explaining that a predecessor of Article 6 'emphasise[d] that the provisions of the Uniform Law are supplementary and yield to the agreement of the parties'); see also Bianca and Bonell, supra note 2, 80 (casting 'the principle of the parties' autonomy' as one of the general principles underlying the Convention); AH Friedman, 'The UN Convention on Contracts for the International Sale of Goods' (1988) 7 Digest of Commercial Laws of the World 1, 3 (citing Article 6 and concluding that "[the] primacy of the parties['] autonomy is the very essence of the Convention'). The principle of party autonomy is also manifest in Article 1(1)(b), which essentially permits qualifying paries to choose whether the Convention will govern their contract, see CISG, supra note 1 , Article l(1), l(1)(b), S Treaty Doc no 9, at 22, 19 ILM 672 (providing that the 'Convention applies to contracts of sale of goods between parties whose places of business are in different States ... when the rules of private international law lead to the application of the law of a contracting State' and thereby allowing parties, through the private international law principle that the law the parties designate will govern, to choose whether the Convention will apply to their contract), and in Article 9, which permits usages expressly or impliedly adopted by the parties to trump conflicting provisions of CISG, see CISG, supra note 2, Article 9, S Treaty Doc no 9, at 24, 19 ILM 674; 'Commentary on the Draft Convention on Contracts for the International Sale of Goods, Prepared by the Secretariat, UN Conference on Contracts for the International Sale of Goods' Article 8, cmt 5, at 19, UN Doc A/Conf 97/19 (1980), in Documentary History, supra note 2, 409 ('Since usages which become binding on the parties do so only because they have been explicitly or implicitly incorporated into the contract, they will be applied rather than conflicting provisions of this Convention on the principle of party autonomy.'); 'UN Conference on Contracts for the International Sale of Goods 1st committee, 6th meeting', 77, at 264, UN Doc A/Conf 97/19 (1980), in Documentary History, supra note 2, 485 (In the Argentinian representative's view, the rules embodied in the predecessor of Article 9 were manifestations of 'the principle of the autonomy of the will of the parties".); Bianca and Bonell, supra note 2, 107 ("The fact that the parties are bound by usages to which they have agreed derives from the general principles of party autonomy (Article 6).'). 
Article 11 that contracts 'need not be concluded in or evidenced by writing',99 authorises parties to a written contract to require, as part of their contract, that any termination or modification be in writing. ${ }^{100}$ Article 6 more expansively enables '[ $t$ ] he parties [to] exclude the application of [the] Convention or, subject to Article 12, derogate from or vary the effect of any of its provisions'. ${ }^{101}$ The derogation permitted by Article 6 need not be explicit; the parties may imply their intent to escape from all or part of the Convention. 102 The parties' intent is controlling. ${ }^{103}$

99 CISG, supra note 2, Article 11, S Treaty Doc no 9, 24, 19 ILM 674.

100 CISG, supra note 2, Article 29(2), S Treaty Doc no 9, 26, 19 ILM 677. Article 29(2) provides in full: 'A contract in writing which contains a provision requiring any modification or termination by agreement to be in writing may not be otherwise modified or terminated by agreement. However, a party may be precluded by his conduct from asserting such a provision to the extent that the other party has relied on that conduct.' $I d$.

101 CISG, supra note 2, Article 6, S Treaty Doc no 9, 23, 19 ILM 673. In spite of the broad language of Article 6, Professors Bianca and Bonell argue that the parties may not escape the application of Article 7. Bianca and Bonell, supra note 2, 93-94.

102 A predecessor of Article 6, Article 3 of the Uniform Law on the International Sale of Goods, explicitly stated that exclusion of the Uniform Law by the parties 'may be express or implied'. Working Group on the International Sale of Goods, 'Report on the Work of the Second Session, 7-18 December 1970' [1971] II UN Comm'n Int'1 Trade L YB 43, at 55, UN Doc A/CN9/Ser A/1971, in Documentary History, supra note 2, 61 (quoting ULIS Article 3). The reference to implicit exclusion was deleted, not to deny power to implicitly exclude application of the Uniform Law, but because "[s]ome representatives were concerned lest the special reference to "implied" exclusion might encourage courts to conclude, on insufficient grounds, that the law had been wholly excluded'. Id 45, 55. A later proposal to permit only express exclusion of the Convention was rejected. See 'Report of the United Nations Commission on International Trade on the Work of its Tenth Session [1977] VIII UN Comm'n Int'l Trade L YB 56-57, at 29, UN Doc A/CN9/Ser A/1977, in Documentary History, supra note 2, 322. According to several representatives, the version of Article 6, which with only numbering changes was finally adopted, permits both express and implied derogation. See 'UN Conference on Contracts for the Intemational Sale of Goods, 1st Committee, 4th meeting', 4, at 248, UN Doc A/Conf 97/19 (1980), in Documentary History, supra note 2, 469 (The chairman of the first committee "considered that exclusion of the application of the Convention, derogation from its provisions or variation of their effect could be either express or implied, [and that] that was also apparently the conclusion which had emerged from the preparatory work'.); id 11, 249, in Documentary History, supra note 2, 470 (According to the Norwegian representative, 'the ... text which[, with non-substantive changes, became Aricle 6] ... meant that derogation might be express or tacit'.); id 25, 250, in Documentary Histon;, supra note 2, 471. (In the United Kingdom representative's view, 'it was not necessary for the parties to indicate expressly that they had decided to exclude the provisions of the Convention and to apply another legal régime, as the existing text of Article 5 [essentially the text adopted as Article 6] might lead one to believe'.); see also Uniform Law, supra note 2, ss 76, 77, at 126, 129 (Because UNCITRAL did not clearly resolve the express-implied exclusion debate, "normal rules of construction of the contract apply to the question of exclusion or modification of the Convention'. As a result, '[the Convention may be excluded by the parties, but only by an express agreement or an agreement that is clearly implied in fact'.); Rhodes, supra note 2, 400, 403 (concluding 'that the delegates reached an impasse in [and did not resolve] the express or implied exclusion debate; though agreeing that 'the stronger argument is ... that parties may exclude the CISG by implication').

103 See 'UN Conference on Contracts for the International Sale of Goods, 1st committee, 4th meeting', 11, at 249, UN Doc A/Conf 97/19 (1980), in Documentary History, supra note 2, 470 (In the Norwegian representative's view, 'Tthe determining factor [in deciding whether the parties have derogated from the Convention] must always be the intention of the partics at the moment of concluding the contract, whether or not such intention [has] been express or implied in Article [8].'). 
The principles, in Articles 6 and 29, of party autonomy and respect for the intent of the partics are consistent with the parol evidence rule. As explained above, through the parol evidence rule, the court identifies and safeguards the parties' intent as to the effect of their writing. If the parties intend their agreement to be an integration, the parol evidence rule prevents the fact finder from considering evidence to the contrary. Absent the parol evidence rule, the fact finder might conclude that the contract embraces terms that the parties did not intend at the time of contracting to include in their agreement. Such a conclusion would violate the parties' autonomy to define the complete terms of their bargain. Application of the parol evidence rule thus advances the principles underlying Articles 6 and 29.

\section{Article 9}

The parol evidence rule similarly conforms with the principles underlying Article 9, which provides that contracting parties are bound by their course of performance; their course of dealing; and well-known, widespread usages which the parties have not excluded through their agreement.104 The parol evidence rule facilitates application of Article 9.105 As noted above, the parol evidence rule admits evidence of course of performance, course of dealing, and usages to supplement or explain the terms of written contracts, whether integrated or not, ${ }^{106}$ thus allowing the fact finder to apply the rules of Article 9 in outlining the contours of the parties' agreement. The parol evidence rule is thus consistent with the principles underlying Article 9.

\section{Articles 12 and 96}

Likewise, the parol evidence rule is consistent with the principle underlying Articles 12 and 96. Many CISG provisions allow contracts to be effected and

104 CISG, supra note 2, Article 9, S Treaty Doc no 9, at 24, 19 ILM 674. Article 9 reads: (1) the parties are bound by any usage to which they have agreed and by any practices which they have established between themselves; (2) the parties are considered, unless otherwise agreed, to have impliedly made applicable to their contract or its formation a usage of which the parties knew or ought to have known and which in international trade is widely known to, and regularly observed by, parties to contracts of the type involved in the particular trade concerned. Id.

105 See 'Legal Analysis of the United Nations Convention on Contracts for the International Sale of Goods (1980)', S Treaty Doc no 9, 98th Cong, 1st Session 4 (1983) (CISG and the UCC both 'give ... contractual effect to' trade usage and course of dealing); Bianca and Bonell, supra note 2, 106 (noting that the treatment given course of dealing in Articles 8 and 9 'almost literally corresponds with' the treatment given course of dealing by UCC ss 1-205, a section that the UCC parol evidence rule incorporales by reference, see UCC ss 2-202(a)); Uniform Law, supra note 2, s 120 , at 177 (describing the UCC approach to usages of trade as similar to that of the Convention). Compare Hillman et al, supra note 24, 3.05[3], 3-23 (Under the UCC, '[c]ourse of dealing and trade usage evidence should be admissible except where all of the evidence, considered preliminarily, clearly demonstrates that the parties specifically intended to exclude a course of dealing or usage of trade') with CISG, supra note 1, Article 9, S Treaty Doc no 9, at 24, 19 ILM 674 (binding the parties, unless they otherwise agree, to their course of dealing as well as to wellknown usages in the relevant trade). But cf Uniform Law, supra note 2, s 122, at 179 (Article 9, not domestic law, dictates 'the circumstances that make a usage applicable').

106 See stura note 30 and accompanying text. 
altered without writing. ${ }^{107}$ Article 96 restricts these provisions by authorising contracting States to declare that they will not be bound by any provision that allows contracts to be formed or altered 'other than in writing'. ${ }^{108}$ Article 12 enforces Article 96 by holding that:

[a]ny provision of Article 11, Article 29 or Part II of this Convention that allows a contract of sale or its modification or termination by agreement or any offer, acceptance or other indication of intention to be made in any form other than in writing does not apply where any party has his place of business in a contracting State which has made a declaration under Article 96 of this Convention. ${ }^{109}$

Together, Articles 12 and 96 'recognise ... that some States consider that it is an important element of public policy that contracts or their modification or abrogation be in writing'. 110 The general principle underlying Articles 12 and 96, then, is one of accommodation: accommodation of States' interest in encouraging, even requiring, that contracts be in writing. ${ }^{11}$ CISG is so committed to this principle of accommodation that it does not allow parties to 'derogate from or vary the effect of [Article 12]'. ${ }^{112}$

The strong accommodationist principle underlying Articles 12 and 96 supports application of the parol evidence rule, for that rule seeks to effect the United States' interests in written contracts by encouraging parties to embody

107 See, for example, CISG, supra note 2, Article 11, S Treaty Doc no 9, at 24, 19 ILM 674 ('A contract of sale need not be concluded in or evidenced by writing and is not subject to any other requirement as to form.'); id Article 29(1), S Treaty Doc no 9, at 27, 19 ILM 677 ('A contract may be modified or terminated by the mere agreement of the parties.').

108 CISG, supra note 2, Article 96, S Treaty Doc no 9, at 41, 19 ILM 693-94. Article 96 provides: 'A Contracting State whose legislation requires contracts of sale to be concluded in or evidenced by writing may at any time make a declaration in accordance with Article 12 that any provision of Article 11, Article 29, or Part II of this Convention, that allows a contract of sale or its modification or termination by agreement or any offer, acceptance, or other indication of intention to be made in any form other than in writing, does not apply where any party has his place of business in that State.' Id.

109 CISG, supra note 2, Article 12, S Treaty Doc no 9, at 24, 19 ILM 674.

110 'Commentary on the Draft Convention on Contracts for the International Sale of Goods, Prepared by the Secretariat, UN Conference on Contracts for the International Sale of Goods Article 11, cmt 1', at 20, UN Doc A/Conf 97/19 (1980), in Documentary History, supra note 2, 410 (commenting on a predecessor of current Article 12).

111 See Bianca and Bonell, supra note 2, 125 ('Article 12 aims at accommodating the special demands of those States whose legal systems impose the written form for contracts of intemational sales for purposes of validity, evidence and administrative control ...').

112 CISG, supra note 2, Article 12, S Treaty Doc no 9, at 24, 19 ILM 674; see also CISG, supra note 2, Article 6, S Treaty Doc no 9,23, 19 ILM 673 ('The parties may ... subject to Article 12, derogate from or vary the effect of any of [the Convention's] provisions.'); 'Commentary on the Draft Convention on Contracts for the International Sale of Goods, Prepared by the Secretariat, UN Conference on Contracts for the International Sale of Goods Article 11, cmt 3, at 20', UN Doc A/Conf 97/19 (1980), in Documentary History, supra note 2, 410 ('Since the requirement of writing in relation to the matters mentioned in Article [12] is considered to be a question of public policy in some States, the general principle of party autonomy is not applicable to ... Article [12]. Accordingly, Article [12] cannot be varied or derogated from by the parties.'); Bianca and Bonell, supra note 2,127 (Article 12 is the only provision of the Convention which is of a mandatory character ...'). 
their contracts in writing, preventing 'perjured or otherwise unreliable testimony of oral terms' to contradict the terms of a writing, and excluding 'prior agreements ... superseded by the [written contract] under a theory of merger'.113 Thus, the parol evidence rule comports with the general principle of accommodation for States' interests in written contracts. 114

In sum, because the parol evidence rule conforms 'with the general principles on which [the Convention] is based', the rule may be applied under Article 7(2) to resolve the unsettled question of what constitutes due consideration of extrinsic evidence in determining the parties' integrationist intent. ${ }^{115}$

\section{Conclusion}

As this article has argued, the parol evidence rule may be seen as an appropriately-international application of Article 8, or alternatively, as a rule, consistent with general principles underlying the Convention, that resolves the question of what constitutes 'due consideration ... [of] all relevant circumstances'116 in determining the parties' intent as to the effect of their writing. Under either of these perspectives, the parol evidence rule may legitimately be applied to contracts governed by the Convention. Thus, while the Fifth Circuit in Beijing Metals failed to reveal the analysis supporting its holding that the parol evidence rule applies to CISG contracts, and while

113 Gordon, supra note 19, 647 (citing J Calamari and J Perillo, The Law of Contracts Third Edition (1987) 137); see supra note 33 and accompanying text. But $c f$ 'Legal Analysis of the United Nations Convention on Contracts for the International Sale of Goods', supra note 105, S Treaty Doc no 9, 6 (recommending that the United States not make an Article 96 declaration; also noting that '[m]ost delegates ... including the United States, concluded that formal requirements [are] inconsistent with modern commercial practice,' thus suggesting that the policies behind the parol evidence rule are not as strong in the international trade arena).

114 It may be argued that Articles 12 and 96 would support application of the parol evidence rule only if the United States had made an Article 96 declaration. Because United States legislation does not uniformly require contracts to be in writing, however, such a declaration would not have been appropriate or even available to the United States. See CISG, supra note 2, Article 96, S Treaty Doc no 96, at 24, 19 ILM 674; 'Report of the First Committee, UN Conference on Contracts for the International Sale of Goods' 1st Comm', Article 10, 7(iv), at 91, UN Doc A/Conf 97/19 (1980), in Documentary Histony, supra note 2, 663 (recording that a Netherlands' proposal - which would have allowed States to make an Article 96 declaration to require only certain types of contracts to be in writing - was rejected). But of Declarations Table, supra note 3, 286 (noting that '[the People's Republic of China does not consider itself to be bound by ... Article 11 as well as the provisions in the Convention relating to the content of Article 11' even though China apparently did not make an Article 96 declaration). Nor could the United States have lodged a reservation to CISG provisions allowing contracts to be effected or modified without a writing, for '[n]o reservations are permitted except those expressly authorised in this Convention.' CISG, supra note 2, Article 98, S Treaty Doc no 9, at 42, 19 ILM 694. Thus, the United States appropriately adopted the Convention without making a declaration or reservation to the Convention's oral contracting allowances. Just as appropriately, the United States may apply the parol evidence rule in harmony with the articles that accommodate Stules' interests in written contracts.

115 CISG, supra note 2. Article 7(2), S Treaty Doc no 9, at 24, 19 ILM 673.

116 CISG, supra note 2, Article 8(3), S Treaty Doc no 9, at 24, 19 ILM 673. 
commentators such as Professor Flechtner have contested that holding, this article's analysis justifies the court's conclusion. This article thus supplements the decision in Beijing Metals, strengthening that decision as a worldwide precedent while simultaneously laying bare the opinion's possible reasoning to attack by supporters of a strictly international interpretation of CISG. 